Marquette University

e-Publications@Marquette

Philosophy Faculty Research and Publications

Philosophy, Department of

$1-1-2011$

\title{
Truth Commissions and Human Rights
}

Margaret Urban Walker

Marquette University, margaret.walker@marquette.edu

Accepted version. "Truth Commissions and Human Rights," in Handbook of Human Rights. Ed. Thomas Cushman. New York: Routledge, 2012: 500-507. DOI. (C) 2012 Routledge. Used with permission.

Margaret Urban Walker was affiliated with Arizona State University at the time of publication. 


\title{
Truth Commissions and Human Rights
}

\author{
Margaret Urban Walker \\ Arizona State University
}

Truth commissions are the institution most emblematic of the emerging principle that individual victims of political violence and mistreatment, and societies in which serious human rights violations obtain, are entitled to an investigation and disclosure of facts concerning these abuses (on the emerging principle, see Méndez 1997 and 2006). In the aftermath of armed conflict or severe political repression, truth commissions are temporary institutions charged with discovering, and disseminating in a final report, a truthful record of events, causes, patterns, and individual or institutional responsibilities pertaining to specified human rights violations during a particular period of time (Minow 1998; Rotberg and Thompson 2000; Hayner 2001; Freeman 2006; Borer 2006). Other means of uncovering, documenting, and disseminating the truth about human rights abuses include the authoritative findings of criminal judicial proceedings or of "truth trials"; reports by human rights organizations and national, intergovernmental, and international bodies and organizations; the opening of previously secret state files; the excavation and forensic study of human remains; the revision of history texts for use in schools; and research, educational, archival, or memorial projects by governmental or nongovernmental entities. Yet truth commissions have rapidly become a standard transitional justice measure following violence, repression, or conflict, refined over the past three decades by accumulated experience, the articulation of international norms prescribing truth recovery, and the technical support of international organizations (see United Nations High Commissioner on Human Rights 2006). Widespread and rapid proliferation of truth commissions and ambitious claims made for what truth commissions might do has prompted closer scrutiny of these claims, research on the efficacy of truth commissions, and consideration of the limitations and tensions inherent in truth commission proceedings and aims. Section I looks at the evolution of a human right to the truth about human rights violations in international instruments. Section II overviews diverse 
claims made for what truth commissions aim at or accomplish. Section III registers some critical concerns about truth commissions or the claims made about their effects.

\section{A Right to the Truth}

A 2005 draft resolution on the United Nations Commission on Human Rights requested that a study by the Office of the United Nations High Commissioner of Human Rights define the basis, scope and content of a "right to the truth," and best practices and recommendations for the implementation of this right in the aftermath of conflict or of massive or systematic human rights violations (United Nations 2005b). The resolution mentions both judicial and non-judicial truth-seeking mechanisms "such as truth and reconciliation commissions." The "Study on the Right to the Truth"(hereafter, "the Study"), submitted in 2006, traces the legal and historical basis for the right, finding recognition of the right in international treaties and instruments; national, regional and international jurisprudence; and resolutions of universal and regional intergovernmental bodies (United Nations 2006a). The right to the truth is "both an individual and a collective right" (paragraph 36) held by victims of gross human rights violations, their families and relatives, and also "society" (paragraph 58). The truth in question encompasses: causes leading to the individual victim's victimization; causes and conditions pertaining to the violation of international human rights and humanitarian law; progress and results of investigations of violations; circumstances and reasons for the perpetration of the violations; the circumstances in which violations took place; the fate and whereabouts of victims if dead or missing; and the identity of perpetrators (subject to appropriate safeguards) (paragraphs 38-40). The 2006 Study acknowledges multiple mechanisms that can implement the right to the truth, including international and national criminal tribunals, truth trials (judicial proceedings limited to investigations and the compilation of case files, without prosecution), truth commissions, national human rights institutions, archives, administrative and civil proceedings, and historical projects (paragraphs 47-54). It concludes that the "the right to the truth about gross human rights violations and serious violations of human rights law is an inalienable and autonomous right," (paragraph 55) and a "non-derogable right" not subject to limitations (paragraph 60). A follow-up report by the Office of the High Commissioner for Human Rights in 2007 surveys responses to the 
Study by 16 countries and several nongovernmental organizations (United Nations 2007). It describes the right to the truth as "evolving steadily" (paragraph 87) and recommends further in-depth study of the contribution of criminal justice systems, the protection of records and archives concerning human rights violations, and the institutional means, procedures, and mechanisms for implementing the right to the truth (paragraph 92).

What aims of the right to the truth do these documents identify? The 2006 Study notes that legal acts establishing truth commissions in particular "ground themselves in the need of the victims, their relatives and the general society to know the truth about what has taken place; to facilitate the reconciliation process; to contribute to the fight against impunity; and to reinstall or to strengthen democracy and the rule of law," a fairly sweeping agenda (United Nations 2006a, paragraph 14). The Study adds the objective for truth commissions of "making a credible historical record and thereby to prevent the recurrence of such events," and notes that some truth commissions provide "a cathartic forum for victims, perpetrators and the broader society to publicly discuss violations, often with the ultimate aim of reconciliation and sometimes to achieve a measure of justice" (paragraph 15). While the individual's right to the truth functions instrumentally to the fulfillment of other rights, such as individual victims' (and families' and relatives') rights to investigation and information, to access justice, to an effective remedy, to reparation, and so forth, the Study links individual access to truth to "a basic human need" and to addressing the "anguish and sorrow" of, for example, families of the disappeared. The societal aspect of a right to truth centers on creating a credible historical record with intent to prevent repetition of documented violations. The 2007 response reports that some states hold that the "purpose" of the right to the truth is "to restore to the victims of manifest violations of human rights their dignity and to ensure that such misdeeds do not recur" (United Nations 2007, paragraph 13). Recent conceptualization of the right to the truth thus encompasses both victim-centered and societycentered aims.

The path to recent recognition of the right to the truth as an inalienable and autonomous right passes through other international instruments, especially those concerning principles for combating impunity and principles and guidelines concerning the victim's rights to

Handbook of Human Rights, (September 7, 2011): pg. 500-507. Publisher Link. This article is (C Taylor \& Francis (Routledge) and permission has been granted for this version to appear in e-Publications@Marquette. Taylor \& Francis (Routledge) does not grant permission for this article to be further copied/distributed or hosted elsewhere without the express permission from Taylor \& Francis (Routledge). 
a remedy and reparation in the wake of gross human rights violations and serious violations of humanitarian law. (Also relevant are guidelines on internal displacement and on enforced disappearance). The Updated Set of Principles (hereafter, "Set of Principles") to combat impunity puts "the right to know" of victims and of "a people" among the three categories of principles for combating impunity, alongside the right to justice and the right to reparation (United Nations 2005a). The Set of Principles lists first the inalienable right of "every people" to know "the truth about past events concerning perpetration of heinous crimes" as a "vital safeguard against the recurrence of violations" (Principle 2), and gives separate place to the duty to "preserve the collective memory from extinction and, in particular, at guarding against the development of revisionist and negationist arguments" (Principle 3). Finally and separately, the Set of Principles asserts the "imprescriptable right to know the truth" of victims and their families about violations they have suffered (Principle 4). The Set of Principles gives special attention to the establishment and role of truth commissions (Principles 6-13) and to the preservation of archives and public access to them (Principles 14-18), although not to the exclusion of judicial investigation and criminal prosecution as other truth recovery paths. The Set of Principles thus gives a somewhat fuller emphasis to the societal dimensions of a right to truth, stressing the aims of preventing both future reoccurrence of violations and the denial of past violations. While preventing denial may be seen as serving to prevent repetition, the Set of Principles seems to underscore the independent claim a society or people has to accurate collective memory, saying "A people's knowledge of the history of its oppression is part of its heritage and, as such, must be ensured..." (Principle 3). This emphasis on a collective right of a people to know its history and on the idea of truth as the heritage of a people was present in the original articulation of principles to combat impunity (sometimes called the Joinet principles) that speaks in the plural of "the main objectives of the right to know as a collective right," mentioning prevention of violations by drawing on history and guarding against the "perversions" of history through revisionism and negationism (United Nations 1997).

The Basic Principles and Guidelines on the Right to a Remedy and Reparation (United Nations 2006b; hereafter "Basic Principles") specifies three categories of remedies to which victims of gross human

Handbook of Human Rights, (September 7, 2011): pg. 500-507. Publisher Link. This article is (C Taylor \& Francis (Routledge) and permission has been granted for this version to appear in e-Publications@Marquette. Taylor \& Francis (Routledge) does not grant permission for this article to be further copied/distributed or hosted elsewhere without the express permission from Taylor \& Francis (Routledge). 
rights violations have a right: access to justice; reparation; and relevant information concerning violations and reparations mechanisms. The right to the truth concerning violations appears in a dual role. There is an entitlement of victims and their representatives to "learn the truth" about the causes of their victimization and on causes and conditions pertaining to the gross violations of human rights (Section $\mathrm{X}$ ). In addition, among the reparations measures to which victims are entitled are forms of "satisfaction," including the right to "verification of the facts and full and public disclosure of the truth" (consistent with the well-being of the victim and others involved); to a search for the whereabouts of the disappeared, the identities of abducted children, and the remains of those killed; and to the inclusion of "an accurate account of the violation that occurred in international human rights law and international humanitarian law training and in educational material at all levels" (Section IX, 22, b, c, and $h$ ). The Basic Principles recognizes that groups of victims may be targeted collectively, and that groups should be able to claim reparation (Section VIII, 13). "Society" or "a people" do not figure into these guidelines for the rights of individuals, except insofar as it is considered a form of satisfaction, and hence a kind of reparations to individual victims, for the truth about violations to be embodied in legal training and educational materials, presumably to insure that the reality and their experience of violation is preserved and given authoritative status. Unlike the Study and The Set of Principles, The Basic Principles do not explicitly link the entitlement of victims to a truthful accounting to guarantees of non-repetition. Guarantees of non-repetition are treated as a distinct kind of reparations, and entitlements to truth are not directly associated with the aim of preventing future violence. The Preamble to the Basic Principles does, however, mention not only the plight of and benefits to the victim and survivors, but also "future human generations" as a concern (Preamble).

In summary, the central understandings embodied in international instruments through which an autonomous right to the truth has evolved appeal both to interests and needs of victims and families, as well as to societal interests and needs. Needs and interests of victims and families include psychological needs to be relieved of suffering and needs for the reaffirmation of dignity. The societal interests include knowledge that leads to effective prevention of

Handbook of Human Rights, (September 7, 2011): pg. 500-507. Publisher Link. This article is (C Taylor \& Francis (Routledge) and permission has been granted for this version to appear in e-Publications@Marquette. Taylor \& Francis (Routledge) does not grant permission for this article to be further copied/distributed or hosted elsewhere without the express permission from Taylor \& Francis (Routledge). 
abuses, but also interests in truthful collective memory as a people's heritage.

\section{The Aims of Truth Commissions}

A truth commission is a temporary body constituted to gather information and testimony relevant to determining, and delivering in a final report, a true and authoritative record of human rights abuses during a specified period of violence, repression, or conflict. Truth commissions and the international instruments that affirm the rights of victims and societies to know the truth about episodes of violence and repression have developed in tandem in recent decades. There have been over forty truth commissions. Truth commissions have become an accepted, and often expected, way of addressing victims' and societies' rights to the truth. All truth commissions share the core task of investigating, clarifying, and disseminating certain truths about episodes or eras of human rights abuse. Yet truth commissions differ considerably in their origins, constitution, mandates, powers, legitimacy, and resources. Truth commissions can be charged to examine relatively compressed periods or decades of abuse (a threeyear period in Haiti; a thirty-six-year armed conflict in Guatemala; decades of removal of mixed-race Aboriginal children in Australia). They can be established by executive order (Argentina; Chile), legislative action (South Africa), or through internationally brokered agreements (El Salvador; Timor Leste); some prominent truth recovery reports have been generated unofficially, by extragovernmental entities (Brazil).

There can be many truth commissioners or few, who are appointed through different processes (three non-Salvadorans appointed by the Secretary-General of the United Nations to El Salvador's Commission; in Argentina, 12 nationals, and in Chile 8 Chileans, named by the President; in Guatemala, 2 Guatemalans named from within and 1 non-Guatemalan United Nations representative; in South Africa, 17 South Africans, representing varied constituencies, selected through a highly consultative process within the country). Resources vary greatly (a \$10 million Guatemalan budget; over $\$ 30$ million in South Africa). Officially empowered truth commissions may enjoy more or fewer investigative powers, such as those of search and subpoena (South Africa's TRC enjoyed significant subpoena, search, and seizure powers it rarely used; Timor Leste's 
commission could impose criminal penalties on individuals for failures to cooperate or for intimidating witnesses; earlier Latin American commissions had no such powers). The mandates of truth commissions can leave more or less room for interpretation of their investigative mission. Truth commissions are not tasked to tell simply "the truth" or "the whole truth;" rather, their mandates provide terms of reference that indicate with varying degrees of precision which kinds of violations are to be investigated and the period of conflict or repression to be examined. The violations under investigation are usually those that qualify as grave or gross abuses of human rights, in particular, such crimes "on the body" as disappearance, extra-judicial execution, torture, arbitrary detention, and more recently, rape and other sexual violence and forced recruitment. East Timor's Commission for Reception, Truth and Reconciliation, however, developed an innovative system of Community Reconciliation Procedures to deal with restitution by perpetrators for lesser harms such as theft, assault, or damages to property. Truth commissions are not usually charged to examine socio-economic or social-structural issues, although these may play a role in a commission's explanatory task. Recommendations for the reform of institutions (especially, judicial, military, penal, and security ones) are always among a truth commission's recommendations.

Resources and time constraints determine how much a commission can do. Some commissions have focused on illustrative or "window" cases to illuminate broader patterns of violence (EI Salvador), while others have tried to make determinations in as many individual cases as they can (around 3,400 individual cases in Chile's National Commission on Truth and Reconciliation; more than 7,500 cases in Guatemala's Commission for Historical Clarification). In either approach, it is inevitable that many cases will go unreported, and of those reported, many will receive no additional investigation. While the global fame of South Africa's Truth and Reconciliation Commission made public testimonies of (a minority of) victims a new standard to which later commissions conformed (Peru, Timor-Leste), significant earlier commissions (Chile, Haiti, Argentina) proceeded in private, making their findings known only through a final report. While the TRC's perpetrator testimony in amnesty hearings was often riveting, the TRC's controversial procedure of trading truth for information has not been repeated. Some truth commissions have identified 
perpetrators by name in their final reports (Chad, El Salvador, South Africa), while others have not (Chile; Guatemala), and some have referred the names of individuals confidentially to other authorities (Chile, Argentina, Timor-Leste). Organizations such as the International Center for Transitional Justice offer information, support, and training for truth commissions, and there are both technical challenges (for example, ways to obtain, organize, and assess data) and human concerns (for example, how to protect the safety and deal with the material and psychological needs of victims and witnesses) about which much has been learned. Local circumstances and resources, however, leave many choices open for the design, authority, and operation of truth commissions in their particular political, social, and cultural context.

The mandates that establish the scope and powers of truth commissions, and the final reports that truth commissions are always charged to return, identify a variety of aims that justify and guide their work. (Discussions that enumerate aims include Hayner 2001, 24; Méndez 2006, 144; Borer 2006b, 26). The most fundamental task of a truth commission is to tell the truth - about individual cases, overall patterns, or both - it is charged to tell; this aim, while obvious, is not in fact simple (see next section). All truth commission mandates and reports, however, claim that the commission should or can serve a variety of other important goals for victims of violence and their society, and these goals are diverse (see United States Institute of Peace Truth Commissions Digital Collection (n.d.) for many mandates and truth commission reports). The two of the most commonly stated goals of truth commissions are to "restore the dignity" of victims of severe abuses, and to establish the truth so as to prevent a reoccurrence of the violations documented. Other goals stated either by commissions or by the surrounding literature include: recognizing the suffering of victims and of families; promoting the healing of victims and providing a cathartic experience; preserving the memory of victims; creating public accountability for individual perpetrators, institutions, or society at large; combating impunity of perpetrators of gross abuses; rehabilitating and reintegrating perpetrators; recommending institutional reforms to prevent repetition; recommending appropriate reparations for victims; recommending prosecutions; preventing denial and revisionist histories; confronting public ignorance of abuses and their consequences; creating a new 
national narrative and a shared collective memory; contributing to national reconciliation; promoting a culture of respect and human rights; strengthening democracy and the rule of law.

Many aspirations of truth commissions clearly depend on factors that lie beyond what a commission itself can accomplish or control (for example, strengthening democracy or fostering national reconciliation), while others fall within the tasks that are a constitutive part of a commission's assigned work (producing a credible record or recommending reforms and reparations). The aim of restoring or affirming the dignity of victims, avowed by all truth commissions, seems to lie between. When a commission hears victims' stories, it validates victims' sense of injustice by confirming their experience of abuse and, in recent commissions, gives some victims a public stage to speak out against their abusers. Yet whether victims will feel that they have been adequately recognized, their suffering addressed, and their claims to justice honored can depend as well on actions the truth commission itself cannot take (for example, criminal trials or other incapacitation of perpetrators, reparations, memorials, or widespread public acceptance of the findings a commission offers). It is clear that only some effects of a truth commission process or its products may be distinguished and assessed in the short term. Longer term contributions to personal well-being, or to social and political developments, are not easily assessed (but see DeGreiff 2006 and Brahm 2007).

\section{Critical Responses to Truth Commissions}

How well do truth commissions serve the individual and collective human right to the truth? Many claims have been made for the salutary effects of victim participation in truth commissions, the societal acknowledgment they represent, or the longer term preventive impact of an accurate history of human rights abuse. A recent wave of research on the effects of truth commissions promotes closer scrutiny, and some skepticism, about what truth commissions have been shown to do, or can be expected to do.

There is not yet a large body of evidence concerning truth commissions' impacts, and most research has focused on the South African Truth and Reconciliation Commission (Chapman \& van de Merwe 2008). Although victims uniformly strongly support and value truth-telling, evidence for the therapeutic value of truth commissions 
for victims is ambivalent and does not support strong claims of individual psychological benefit (Mendeloff 2009). Therapeutic effects are unlikely in any case, as most victims who give a statement to a truth commission have a brief encounter with a statement taker, and even the minority of victims who testify publicly do not thereby receive sustained therapeutic attention. Moral and political recognition of victims' dignity achieved through public acknowledgment and giving voice to victims is not reducible to psychological effects, but may remain largely (if meaningfully) symbolic without other measures to ensure justice and material and social support (Walker 2010). Deeply individual issues of mourning and reparation cannot be expected to coincide with social and political imperatives to "move on" in the transition; at the same time, victims seek truth, justice, and accountability, which are deeply linked to their sense of individual reparation (Hamber 2009).

The contribution of truth commissions to a society's reckoning with its own past is highly dependent on the record the truth commission establishes, a commission's own legitimacy and authority, the credibility and wide dissemination of its findings, and a significant impact on public understandings and attitudes. Any unilateral direct effect of a truth commission on the prevention of future violence or repression is unlikely, although implementation of recommendations made by a commission on the basis of its findings might have important preventive functions. Whatever the contribution, short or long term, to the resolution of conflict, the rule of law, and future stability a truth commission might make, it is likely that other factors, particularly structural changes (legal, economic, and political), a political environment that supports dissemination and discussion of truth commission findings, and action on the commission's most urgent recommendations will play a decisive role (Fletcher and Weintstein, with Rowe 2009). Still, publicity of truth commission proceedings and wide dissemination efforts, as in South Africa, have been found to produce some notable effects, such as recognition by a large majority there that the system of apartheid was a crime against humanity and some apparent impact of the TRC process and findings on reconciliation, as defined by several measures (Gibson 2004). If these outcomes are valid for South Africa, however, it does not follow that a truth commission process will produce similar results elsewhere. Even in a given setting, it is possible that not all truth commission

Handbook of Human Rights, (September 7, 2011): pg. 500-507. Publisher Link. This article is @ Taylor \& Francis (Routledge) and permission has been granted for this version to appear in e-Publications@Marquette. Taylor \& Francis (Routledge) does not grant permission for this article to be further copied/distributed or hosted elsewhere without the express permission from Taylor \& Francis (Routledge). 
goals are compatible; pressing issues of accountability may not, for example, conduce to stability or reconciliation (Leebaw 2008).

At its core, every truth commission is charged to accomplish one task, whatever hoped-for effects eventuate or not. A truth commission is supposed to produce a truthful accounting of actions and events within its mandate, as well as the circumstances and patterns that provide context and explanation of what has occurred, including the actions or failures to act of individuals (whether identified or not), groups, and institutions. Scrutiny of truth commission operations of gathering, assessing, and organizing evidence and testimony has produced mixed verdicts on, and some skepticism about, the completeness, accuracy, and relevance of the truth that actual truth commissions have told. There are tensions between the desires of individuals to have their testimonies heard and respected, and to find out more information about their specific cases or the fate of the loved ones they have lost, and the role of truth commissions in determining a larger comprehensive narrative of causes and patterns of violence and repression. The micro-level truths of individual cases and the macro-level truth of patterns and trends pose different demands on data-gathering and analysis, and truth-commission methodologies may fail to meet either or both of these tasks adequately (Chapman and Ball 2001). Truth commissions, starting with South Africa's TRC, have taken an increasingly sophisticated view of the multiple kinds of truth (factual, narrative, dialogical, restorative) that a commission must confront. Nonetheless, tensions between a legalistic model of establishing facts relevant to particular abuses of domestic, international human rights, and international humanitarian law; giving voice and a dignifying role to victims through individual, and sometimes public, testimonies of victims, relatives, and witnesses; and engaging in systematic data collection to establish empirically sound generalizations, are not easily overcome in the context of time-limited and resource-constrained truth commissions. It may be that disaggregation of truth commissions' truth-recovery functions, and longer term projects of ongoing collection and analysis of data beyond the time and scope of a truth commission, is one way to address these tensions. A truth commission, however, is not a research project in pursuit of a disinterested truth. It is an institution structured by moral and political purposes meant to capture some particular truths urgently needed in specific political contexts, and in doing so to

Handbook of Human Rights, (September 7, 2011): pg. 500-507. Publisher Link. This article is (C) Taylor \& Francis (Routledge) and permission has been granted for this version to appear in e-Publications@Marquette. Taylor \& Francis (Routledge) does not grant permission for this article to be further copied/distributed or hosted elsewhere without the express permission from Taylor \& Francis (Routledge). 
NOT THE PUBLISHED VERSION; this is the author's final, peer-reviewed manuscript. The published version may be accessed by following the link in the citation at the bottom of the page.

announce commitments to human dignity and responsibility that are embedded in the framework of human rights.

\section{References}

Borer, Tristan Anne, ed. 2006. Telling the Truths: Truth Telling and Peace Building in Post-Conflict Societies. Notre Dame, Ind.: University of Notre Dame Press.

Brahm, Eric. 2007. Uncovering the Truth: Examining Truth Commission Success and Impact. International Studies Perspectives 8: 16-35.

Chapman, Audrey R. and Patrick Ball. 2001. The Truth of Truth Commissions: Comparative Lessions from Haiti, South Africa, and Guatemala. Human Rights Quarterly 23: 1-43.

Chapman, Audrey R. and Hugo van der Merwe. 2008. Truth and Reconciliation in South Africa: Did the TRC Deliver? Philadelphia: University of Pennsylvania Press.

de Greiff, Pablo. 2006. Truth-telling and the Rule of Law. In Telling the Truths: Truth Telling and Peace Building in Post-Conflict Societies, ed. Borer, Tristan Anne. Notre Dame, Ind.: University of Notre Dame Press.

Fletcher, Laurel E. and Harvey M. Weinstein, with Jamie Rowen. 2009. Context, Timing and the Dynamics of Transitional Justice: A Historical Perspective. Human Rights Quarterly 31: 163-220.

Mark Freeman, Truth Commissions and Procedural Fairness (New York: Cambridge University Press, 2006).

Gibson, James L. 2004. Overcoming Apartheid: Can Truth Reconcile a Divided Nation? New York: Russell Sage Foundation.

Hamber, Brandon. 2009. Transforming Societies after Political Violence: Truth, Reconciliation, and Mental Health. Dordrecht: Springer.

Hayner, Priscilla, Unspeakable Truths: Confronting State Terror and Atrocity (New York: Routledge, 2001.

Leebaw, Bronwyn Anne. 2008. The Irreconcilable Goals of Transitional Justice. Human Rights Quarterly 30: 95-118.

Minow, Martha. Between Vengeance and Forgiveness: Facing History After Genocide and Mass Violence. (Boston: Beacon Press, 1998).

Mendeloff, David. 2009. Trauma and Vengeance: Assessing the Psychological and Emotional Effects of Post-Conflict Justice. Human Rights Quarterly 31 (2009): 592-623.

Méndez, Juan E.. 1997. Accountability for Past Abuses. Human Rights Quarterly 19: 255-82.

Méndez, Juan E. 2006. The Human Right to Truth: Lessons Learned from Latin American Experiences with Truth Telling. In Telling the Truths: Truth Telling and Peace Building in Post-Conflict Societies, ed. Tristan Anne Borer. Notre Dame: University of Notre Dame Press.

Handbook of Human Rights, (September 7, 2011): pg. 500-507. Publisher Link. This article is (C) Taylor \& Francis (Routledge) and permission has been granted for this version to appear in e-Publications@Marquette. Taylor \& Francis (Routledge) does not grant permission for this article to be further copied/distributed or hosted elsewhere without the express permission from Taylor \& Francis (Routledge). 
NOT THE PUBLISHED VERSION; this is the author's final, peer-reviewed manuscript. The published version may be accessed by following the link in the citation at the bottom of the page.

Rotberg, Robert I. and Dennis Thompson, eds. 2000. Truth v. Justice: The Morality of Truth Commissions. Princeton, N.J.: Princeton University Press.

United Nations, Commission on Human Rights. 1997. Question of the impunity of perpetrators of human rights violations (civil and political): Revised final report prepared by Mr. Joinet pursuant to SubCommission decision 1996/119. United Nations Document E/CN.4/Sub.2/1997/20/Rev.1, 2 October 1997.

United Nations, Commission on Human Rights. 2005a. Impunity: Report of the independent expert to update the Set of principles to combat impunity, Diane Orentlicher, Addendum, Updated Set of principles for the protection and promotion of human rights through action to combat impunity. United Nations Document E/CN.4/2005/102/Add. 1, 8 February 2005.

United Nations, Commission on Human Rights. 2005b. Promotion and Protection of Human Rights: 2005/...Right to the Truth. United Nations Document E/CN.4/2005/L.84, 15 April 2005.

United Nations, Commission on Human Rights. 2006a. Study on the right to the truth: Report of the Office of the United Nations High Commissioner for Human Rights. United Nations Document E/CN.4/2006/91, 8 February 2006.

United Nations, General Assembly. 2006b. Basic Principles and Guidelines on the Right to a Remedy and Reparation for Victims of Gross Violations of International Human Rights Law and Serious Violations of International Humanitarian Law. United Nations Document A/RES/60/147, 21 March 2006.

United Nations, Human Rights Council. 2007. Rights to the Truth: Report of the Office of the Higher Commissioner for Human Rights. United Nations Document A/HRC/5/7, 7 June 2007.

United Nations High Commissioner of Human Rights. 2006. Rule-of-Law Tools for Post-Conflict States: Truth Commissions. New York and Geneva: United Nations.

United States Institute of Peace, Truth Commissions Digital Collection, at http://www.usip.org/library/truth.html\#tc, accessed 9 January 2010. Walker, Margaret Urban. 2010. Truth Telling as Reparations. Metaphilosophy 41 (2010), at press.

Handbook of Human Rights, (September 7, 2011): pg. 500-507. Publisher Link. This article is (C Taylor \& Francis (Routledge) and permission has been granted for this version to appear in e-Publications@Marquette. Taylor \& Francis (Routledge) does not grant permission for this article to be further copied/distributed or hosted elsewhere without the express permission from Taylor \& Francis (Routledge). 